\title{
Martial Law, the Privy Council and the Zulu Rebellion of 1906
}

On 9 February 1906, martial law was declared in Natal. It followed the murder, on the previous day, of two white policemen near Byrnetown. The officers had come from Richmond to arrest twenty-seven African men, who had earlier defied a magistrate collecting the recently imposed poll tax. There had been rumours for several weeks about an increasingly defiant attitude among the Africans, stoking fears of an imminent rebellion. When the Richmond magistrate came to collect the tax, the crowd he met brandished their spears at him, and said, 'there will be blood today.' ${ }^{\text {' }}$ When Sub-Inspector S. H. K. Hunt and Trooper George Armstrong came to make their arrests, the men were still armed and in no mood to co-operate. During the ensuing melee, Hunt fired a shot into the crowd, injuring one of the Africans, and prompting the attack in which both men were stabbed to death.

The murder of Hunt and Armstrong was the first act in the Zulu Rebellion of I906, which came to be known as the Bambatha rebellion. Although it was provoked by the heavy-handed imposition of a new tax, the rebellion was fuelled by deeper resentments against a colonial government which had undermined traditional Zulu structures of authority, proletarianised much of its youth, and restricted access to land. ${ }^{2}$ For two months, resistance took a passive

${ }^{\text {I }}$ Proceedings of Richmond Court Martial, CO I79/234/I9935, f. 495.

${ }^{2}$ For different interpretations of the causes of the rebellion, see Shula Marks, Reluctant Rebellion: The 1906-1908 Disturbances in Natal (Oxford, Clarendon Press, 1970); John Lambert, Betrayed Trust: Africans and the State in Colonial Natal (Scottsville, 
form, with communities defying the demands of local magistrates for the tax to be paid. Resistance turned to revolt at the beginning of April, when Bambatha kaMancinza - who had been deposed as Zondi chief in early March - abducted the man appointed to replace him, and ambushed a police column, killing three policemen. When troops were sent to quell his rebellion, he took to the forests of Nkandhla, where he was joined by the elderly Cube chief Sigananda and his son Ndabaningi. The government offered a reward for Bambatha's capture, dead or alive, and pitched battles followed, with many casualties. ${ }^{3}$ This phase of the rebellion lasted two months, until LtCol. Duncan McKenzie's troops routed Bambatha at Mome Gorge on Io June, decapitating the rebel leader, and capturing Sigananda and his followers.

Nine days later, Governor Sir Henry McCallum told his superiors in London that the back of the rebellion had been broken. ${ }^{4}$ In fact, his confidence was premature, for on that same day, two white men were killed in an attack on a store at Thring's Post made by 400 followers of Ndhlovu, chief of the Nodunga section of the Zulu. For the next month, the unrest moved to Maphumulo, where Ndhlovu was joined by the Qwabe chief Meseni. Although Meseni assembled an impi of several thousand fighters, they were able to offer little resistance to the force of some 3,500 led by McKenzie. Ndhlovu and Meseni were captured on I 2 July, with Ndhlovu being blamed for the death of Trooper Powell (killed at Thring's Post), and Meseni held responsible for the death of Oliver Veal, an official of the Public Works Department, whose dismembered body was found at his kraal. ${ }^{5}$ By the end of July, the rebellion had been crushed and the troops

University of KwaZulu-Natal Press, I995); Benedict Carton, Blood from Your Children: The Colonial Origins of Generational Conflict in South Africa (Charlottesville, University of Virginia Press, 2000); Jeff Guy, The Maphumulo Uprising: War, Law and Ritual in the Zulu Rebellion (Scottsville, University of KwaZulu-Natal Press, 2006); Jeff Guy, Remembering the Rebellion: The Zulu Uprising of 1906 (Scottsville, University of KwaZulu-Natal Press, 2006); and Michael R. Mahoney, The Other Zulus: The Spread of Zulu Ethnicity in Colonial South Africa (Durham, Duke University Press, 20I2), ch. 6.

3 McCallum reported before the battle of Mome Gorge that 200 rebels had been killed in fighting up to Io June; on $\mathrm{I}_{3}$ June, he reported that 575 rebels were killed in that battle:

PP 1906 (Cd. 3027) LXXIX. 573, Nos. 5I, 54, pp. 46-47.

4 PP 1906 (Cd. 3027), No. 62, p. 50.

${ }^{5}$ For the trials relating to these issues, see Guy, The Maphumulo Uprising. 
demobilised. However, martial law remained in place until the beginning of October, and would be proclaimed again between December 1907 and August 1908, during which time the colony was at peace, but when the government in Pietermaritzburg was seeking to put together a case of treason against the Zulu king Dinuzulu, who was suspected of being behind the rebellion. ${ }^{6}$

The use of martial law in the Zulu rebellion raised questions about its nature which had remained unsettled at the end of the Anglo-Boer War. In particular, the Privy Council's decision in the Marais case ${ }^{7}$ had left open whether a civilian court could determine the necessity of martial law, and decide whether as a matter of fact a state of war or rebellion existed. ${ }^{8}$ This question came into sharper focus in 1906, since Natal was at peace for much of the time when martial law was in place. During this time, moreover, a selective policy of prosecution in martial law courts was used by the colonial authorities for political purposes, to neutralise potentially rebellious chiefs and to control wider dissent by making swift, public examples of those who either had defied the authorities or might do so. Thanks in no small part to activist supporters of the martial law prisoners in London and Natal - especially the African lawyer Alfred Mangena ${ }^{9}$ and Harriette Colenso $^{\text {IO }}$ - the imperial and colonial authorities had to confront the question of how far such a policy was compatible with the rule of law that British jurists were so keen to champion. The answers they gave were not dictated simply by abstract legal thought, but were rather shaped by their political and cultural world-views. The fact that, in this episode, the targets of martial law were not white British subjects

${ }^{6}$ On the trial, see Marks, Reluctant Rebellion, ch. I I.

7 D. F. Marais v. The General Officer Commanding the Lines of Communication and the Attorney-General of the Colony [1902] AC ro9.

${ }^{8}$ See Sir Henry de Villiers CJ's comments in R. v. Bailly van Reenen and Others (I902) I9 Supreme Court Reports [Cape] 332.

9 See esp. Tembeka Ngcukaitobi, The Land Is Ours: South Africa's First Black Lawyers and the Birth of Constitutionalism (Cape Town, Penguin, 2018); and David Killingray, 'Significant Black South Africans in Britain before I9I2: PanAfrican Organisations and the Emergence of South Africa's First Black Lawyers', South African Historical Journal, vol. 64:3 (20I 2), pp. 393-4I7 at pp. 409-4I6.

ro See esp. Jeff Guy, The View across the River: Harriette Colenso and the Zulu Struggle against Imperialism (Charlottesville, University Press of Virginia, 2002); and Shula Marks, 'Harriette Colenso and the Zulus, г874-19г3', Journal of African History, vol. 4 (I963), pp. 403-4I I. 
whom the local colonial government wished to protect, but subject black Africans whom the colonial government wished to subdue, was crucial to the way the problem was perceived. In this context, liberal voices found a much less receptive audience than had been the case only a few years earlier during the Anglo-Boer war. Although officials at the Colonial Office were troubled by the use of martial law in 1906 , their interventions were constrained by the need to respect the autonomy of a self-governing colony, many of whose officials were more interested in crushing the rebellion than in observing the rule of law. Furthermore, when it came to the matter of passing an indemnity act, Natal's wish to give a simple legislative validation to all actions done under martial law overrode any imperial desire there might have been to subject these actions to any meaningful retrospective review. Finally, when the Privy Council was asked to consider these matters, as the imperial guardian of the rule of law, it showed itself to be as executive-minded and as uninterested in the substantive common law tradition as it had been in the Marais case.

\section{Martial Law before the Rebellion, February-March 1906}

On 23 February, two weeks after martial law had been declared in Natal, Col. H. T. Bru-de-Wald, Commandant of the Natal Militia, gave instructions on how it was to be administered. They seemed to follow the guidelines issued by Lord Carnarvon in 1867 . The ordinary civil and criminal jurisdiction of the civil courts was not to be interfered with, but cases involving sedition, arming or incitement to insurrection were to be dealt with under martial law. Minor cases were to be tried by magistrates, with more serious ones by special courts martial modelled on military courts. ${ }^{\text {II }}$ On the same day, Natal's Minister of Justice, Thomas Watt, confirmed that martial law courts were not to be used to punish 'natives for any acts committed prior to the proclamation of Martial Law' on 9 February. ${ }^{\mathrm{I} 2}$

In fact, there were already signs that these guidelines would not be followed to the letter. Within a week of the murder of Hunt and

\footnotetext{
${ }^{11}$ PP 1906 (Cd. 2905) LXXIX. 503, enc. 2 in No. 30, p. 24. For the Circular of 26 January I 867, see PP I906 (Cd. 2905), Appendix I, p. 55.

I2 CO $879 / 92 / 26$, enc. I in No. 4 , p. 4.
} 
Armstrong, two men - Uzondwein and Njwezi - had already been tried for it and executed by a drumhead court martial. ${ }^{\mathrm{I} 3}$ Although some officials at the Colonial Office, such as Arthur Berriedale Keith, regarded the executions as 'quite needless', there were many voices, both in Natal and in Whitehall, who were prepared to defend them as being necessary 'to prevent a general rebellion'. ${ }^{\mathrm{I}}$ They saw the protests over the poll tax as the prelude to a general rising. Governor McCallum agreed: 'unless an example is made of those who have broken out in rebellion, the movement will be sure to spread.' ${ }^{\text {I5 }}$ Uzondwein and Njwezi would not be the only men tried and executed for the Richmond murders. There would be another trial by a martial law court for this offence on the eve of Bambatha's revolt, and a further civilian trial before the lifting of martial law.

In the weeks before Bambatha's revolt, martial law powers were also used to discipline chiefs who had refused to pay the poll tax or defied the magistracy. During this time, several leaders came under particular suspicion of having encouraged their tribesmen to arm and defy the government: they included chiefs Tilonko, Miskofeli, Ngobizembe and the mixed-race chief Charlie Fynn. In dealing with these men and their followers, the authorities opted to side-step the civilian courts by resorting to martial law powers. Rather than using martial law courts as a last resort to quell a rebellion, they were used in a highly strategic way for political purposes. For instance, although the military had initially been instructed by Natal's defence minister only to assist the police in bringing the followers of chief Ngobizembe to justice (for defying a tax collecting magistrate), attitudes changed after the chief failed to comply with an order to hand them over. 'By virtue of the powers conferred upon me under Martial Law', on ro March Col. George Leuchars imposed a heavy fine on his tribe and dispossessed it of much of its land. Having removed the women and children from the

${ }^{13}$ PP 1906 (Cd. 2905), enc. I in No. 25, p. I4; and James Stuart, A History of the Zulu Rebellion, 1906: And of Dinuzulu's Arrest, Trial and Expatriation (London, MacMillan, I9I3), p. I38.

${ }^{14}$ Minutes by Keith and Fred Graham, CO I79/233/8435, f. I 59. See also H. Cox's question in Parl. Debs., 4th ser., vol. I 52, col. 339 (2 I February 1906), and PP 1906 (Cd. 2905), Nos. I 5 and I7, p. 6. See also Graham's views in CO I79/233/8487, f. I74.

${ }_{15}$ PP I906 (Cd. 2905), No. 25, p. I3; No. 27, p. I6. Cf. CO I79/234/1801 I, f. 367 , Governor to Secretary of State (27 April 1906). 
kraal, his men proceeded to shell it. ${ }^{16}$ Although officials in London doubted the legality of this confiscation, and critical questions were raised in Westminster, ${ }^{\mathrm{I} 7}$ the action induced two other chiefs, Meseni and Swaimane, to give up their offending tribesmen 'contrary to expectations'. ${ }^{\mathrm{I} 8}$

Other chiefs who proved more co-operative in handing over miscreants escaped with lesser fines, while their followers were tried and severely punished by martial law courts. One of these was Miskofeli, whose activities caused the white settlers in the Natal Midlands much anxiety in early 1906. After handing over the wanted offenders, he was subjected only to a fine and the division of his chiefdom. ${ }^{19}$ His followers, by contrast, were put on trial by court martial at Ixopo, where evidence was heard that they armed on the supposition that their chief was about to be arrested, and disbanded when they discovered that this was not the case. ${ }^{20}$ Nevertheless, seven of them were given death sentences, later commuted to imprisonment with hard labour of up to ten years. Another chief whose followers were tried by court martial, while he was merely fined, was Charlie Fynn. Fynn himself favoured paying the poll tax, but had little influence over his tribesmen, who were reported to be ready to resist the government with arms if necessary. Thirty-six of them were tried by a court martial for sedition and inciting to insurrection. Five death sentences were later commuted, with the longest remaining sentence being one of life imprisonment with hard labour. ${ }^{2 \mathrm{I}}$

\section{The Richmond Trial and Its Aftermath}

The middle of March also saw the martial law trial of twenty more men accused of taking part in the Richmond murders of Hunt and Armstrong. They faced charges of public violence, murder and being in arms against the government in a tribunal which followed military

${ }^{16}$ Natal Witness, I7 March I906; PP I906 (Cd. 2905), No. 32, p. 25 ; No. 30, p. 20; CO 789/106/I, Nos. I 83 and I85, pp. 65-66, and Guy, The Maphumulo Uprising, pp. 49-5 I.

${ }^{17}$ Parl. Debs., 4th ser., vol. I 54, col. I247 (28 March 1906); vol. I53, col. 443 (7 March I906); minutes on CO I79/233/I07II, f. 373.

${ }^{18}$ PP 1906 (Cd. 2905), No. 57, p. 36. ${ }_{19}$ Marks, Reluctant Rebellion, p. 196.

${ }_{20}$ PP 1906 (Cd. 2905), Nos. 30 and 39, pp. 20, 29; and Natal Witness, 24 March 1906.

${ }^{21}$ PP 1906 (Cd. 3027), No. 6, p. 6. 
court procedures. When the case began, the men's lawyer, J. F. Jackson, questioned the court's competence to try offences committed before the proclamation of martial law, but without effect. ${ }^{22}$ Sergeant Stephens, who had been injured in the affray, gave evidence relating to the murder, as did several other policemen. Evidence was also given by Mdutshana, the brother of Mjongo, one of the leaders of the protest who had been seriously injured in the affray but was not yet fit for trial. Mdutshana identified thirteen men who were in the party which attacked Hunt, and implicated a number of the defendants. The clearest evidence was against Nkanaysi - who was also not on trial here - who had thrown a spear at Hunt after having himself been shot in the face and in the arm by the policeman. Other witnesses testified that several defendants had thrown spears or stabbed the policemen. One of the accused, Utawini, even admitted that, when they saw Nkanaysi was hurt, 'we threw our assegais'. ${ }^{23}$ On the evidence before it, the court convicted twelve of the men of the murder and sentenced them to death.

The fact that a martial law court had imposed the death sentence would soon raise questions. Even before the trial, Governor McCallum had told his ministers that, in the present condition of the country, the murder charge should be tried by a civilian court. However, Prime Minister Charles Smythe retorted that 'the state of disaffection ... is by no means at an end' and that 'any interference with the court martial now sitting would have a disastrous effect on the natives. ${ }^{24}$ At the same time, McKenzie protested at the commutation of martial law death sentences imposed in the Ixopo trial, insisting that 'this golden opportunity of inflicting the most drastic punishment on all leading natives found guilty' should not be lost. ${ }^{25}$ In response, the Governor agreed to the continuation of martial law trials, but insisted that he (rather than the commandant) would henceforth confirm or revise sentences. Having reviewed the proceedings of the Richmond case with his council, McCallum on 27 March confirmed the Richmond death sentences and the commutations of the Ixopo ones. ${ }^{26}$

22 The transcript of the trial is in CO I79/234/I9935, f. $487 \mathrm{ff}$.

${ }^{23}$ CO I79/234/I9935, f. 56I. ${ }^{24}$ PP I906 (Cd. 2905), No. 57 and enclosures, p. 36.

${ }_{25} \mathrm{CO} 879 / 92 / 26$, enc. 2 in No. 5, p. 9. McKenzie tendered his resignation as a result of the revisions, which the Governor refused: Governor to Secretary of State, 24 March I906, CO I79/233/I3064, f. 366 (redacted in PP 1906 (Cd. 2905), No. 67, p. 4I).

${ }^{26}$ PP 1906 (Cd. 2905), No. 33, p. 25. 
The death sentences immediately attracted attention at the Colonial Office. Keith noted that they could not be justified at common law, and 'as we must assent to an act of indemnity we must be able to do so with a clear conscience.' Even the normally hawkish Fred Graham doubted the wisdom of executing these men under martial law. A telegram was therefore sent to Natal, asking the Governor to suspend the executions until more information had been provided. ${ }^{27}$ The telegram provoked a constitutional crisis in Pietermaritzburg. When Smythe refused to suspend an execution which had already been confirmed in council, McCallum told him he would have to cancel the warrant under prerogative powers. This prompted the resignation of the Natal government ${ }^{28}$ and furious local protests. ${ }^{29}$ The Governor-Generals of both Australia and New Zealand also protested against London's interference with another self-governing colony's right to decide whether to exercise the prerogative of pardon. ${ }^{3 \circ}$ Officials in London were exasperated by Natal's reaction, which entirely overlooked the interests of the imperial authorities, on whose troops the white minority ultimately relied..$^{3 \mathrm{I}}$ However, their eventual response was in the words of Winston Churchill, the undersecretary of state - 'a complete surrender', as officials sent a telegram which explained that the Colonial Office was merely asking for information, rather than seeking to interfere in Natal's constitutional government. ${ }^{32}$

This episode revealed quite how muddy the legal and constitutional waters were where martial law powers were used. The Colonial Office considered that, where matters affected imperial interests, 'the Crown must reserve a certain function to the Secretary of State, and a certain independent function to the Governor. ${ }^{33}$ It also thought that London would ultimately have to assent to any indemnity act, either directly

${ }^{27} \mathrm{CO}$ I79/233/I07I2, f. 379. The telegram (28 March I906) is in PP I906 (Cd. 2905), No. 35 , p. 26.

${ }^{28}$ See PP I906 (Cd. 2905) No. 37, p. 26. See Ronald Hyam, Elgin and Churchill at the Colonial Office, I905-08: The Watershed of the Empire-Commonwealth (London, Macmillan, I968), pp.24I-242.

29 See Natal Witness, 30 March 1906 and the resolutions passed at various public meetings in $\mathrm{CO} \mathrm{I}_{79} / 234 / \mathrm{I}_{5} \mathrm{OI}_{5}$, f. 92.

30 PP 1906 (Cd. 2905), No. 40, p. 32; No. 48, p. 34.

${ }^{31}$ See the draft telegram in H. W. Just's hand in CO I79/233/I Io34, f. 398.

${ }^{2}$ See PP I906 (Cd. 2905), No. 36, p. 26 and No. 38, p. 29, and drafts in CO I79/233/ I07I 2 , f. 385 .

${ }_{33}$ Draft telegram (H. W. Just) CO I79/233/I I034, f. 400. 
or through the imperially appointed Governor. Furthermore, as Churchill publicly pointed out, on the international plane, it would be His Majesty's Government, rather than Natal's, which would be held to account. ${ }^{34}$ Natal's ministry, however, felt that the Governor had to act on the advice of the responsible government, with London having no part to play. The clash of interpretations on this point threatened to unravel what Just referred to as 'the delicate machinery of the British Empire'. Furthermore, if there was disagreement over whom the Governor was answerable to, there was also some uncertainty over the nature of the powers he was exercising. During the spat over whether the men were to be pardoned, officials both in London and in Pietermaritzburg treated the question as one concerning the rightful exercise of the prerogative power of pardon. Yet the men had been convicted by a martial law court, which (as officials in London later realised) was not a judicial act, but an executive act to which that prerogative could not apply. ${ }^{35}$ But the very fact that McCallum had taken the decision to treat these as cases which had to be dealt with 'constitutionally' showed how far he was from seeing martial law as an entirely lawless zone justified only by necessity, and was treating it as a matter within his constitutional powers.

Officials in London were also at odds over the issues at stake. When, in the midst of the crisis, McCallum informed London that McKenzie's column had been demobilised and that the recalcitrant chiefs had paid their fines, ${ }^{36}$ Keith noted that this conclusively proved that Natal was not in a position to execute the men sentenced under martial law. He expressed surprise that no one had applied to the Supreme Court to challenge the sentences, adding that the 'Marais judgment, besides being unintelligible, could not conceivably apply in a case where there has been no actual fighting between whites and blacks'. Keith felt that to execute these men under martial law would be analogous to the execution of George Gordon on Governor Eyre's orders, with the difference being that 'whereas the Jamaica revolt was a real and serious one, the Natal one so far as overt action has gone has been a trifle. ${ }^{37}$ However, Keith's outburst elicited a robust response from

34 Parl. Debs., 4th ser., vol. I 5 5, col. 27I (2 April I906).

35 See minutes by Keith and Just, Io April I906, CO I79/234/I2686, f. I67.

${ }^{36}$ PP 1906 (Cd. 2905), No. 4I, p. 32.

37 Minute, 3 I March 1906, CO I79/233/II32I, f. 5 II. 
his colleague Bertram Cox, who thought him wrong both in law and in policy. As a matter of law, he said, the court had no jurisdiction to review martial law court judgments, for ' $[\mathrm{t}]$ he question whether or not the circumstances of the case justify the continuance of martial law is one of policy primarily for the consideration of the Governor \& his ministers.' This was to take the view that the question of whether martial law was needed or not was settled definitively by the proclamation (a view Keith continued to dispute). As a matter of policy, the line taken by Keith 'of absolutely discrediting the views $\&$ feelings of the men on the spot if put into action will lose us not only $S$ Africa but every colony we possess'. ${ }^{38}$ Keith was soon transferred out of the South African department of the Colonial Office. ${ }^{39}$

\section{The Richmond Trial and the Privy Council}

Although no steps were taken in Natal to challenge the executions, a case was brought to the Privy Council on behalf of the prisoners. It was thanks to the determination of a small group of activists, particularly African students at Lincoln's Inn, that the rebels in Natal would get their cases heard in the highest imperial court. The petitioners were represented by E. G. Jellicoe, a Liberal barrister, ${ }^{40}$ who would later be engaged by Frank Colenso to defend Dinuzulu in his treason trial in 1907. The petition itself was organised by Alfred Mangena, an African law student at Lincoln's Inn, ${ }^{4 \mathrm{I}}$ with legal as well as financial support from Colenso. Born in Natal, Mangena had been a political campaigner in Cape Town on behalf of dock workers who had been forcibly removed to a quarantine location during the bubonic plague outbreak. These campaigns taught him the value of the press

$3^{8}$ Minute, 2 April I906, CO I79/233/II32I, f. 5 I 2.

39 See Hyam, Elgin and Churchill at the Colonial Office, p. 9 and note.

${ }^{40}$ Having acted as solicitor to the Treasury in South Wales, Edwin George Jellicoe emigrated for health reasons to New Zealand in I884, where he practised as a barrister, before returning to England. Having stood for election to the New Zealand House of Representatives, he stood for the Liberal party in the 1906 election and as an independent Liberal in I9го. He was a persistent opponent of Britain's participation in the First World War, and was the author of Playing the Game: What $\mathrm{Mr}$ Asquith in His Book 'The Genesis of the War' Does Not Tell Us (London, John Long, I924).

${ }^{4}$ Mangena was assisted by another African student at Lincoln's Inn (from the Gold Coast), Akilagpa Sawyerr. 
and the law in advancing the cause of the oppressed Africans. He would put these skills to good use in London, where he commenced his legal studies in I903. Having learned from the newspapers of the proclamation of martial law in Natal after the Richmond killings, he strove to bring African grievances about the poll tax in Natal to the attention of the press and politicians, ${ }^{42}$ and to use the courts to challenge the actions of the Natal government under martial law. ${ }^{43}$

Jellicoe's letters informing the Colonial Office that a petition was being lodged in the Privy Council and his requests to have the executions stayed were ignored by the authorities in Natal, since ministers felt that the court would have no jurisdiction, and that this might simply be a case of 'self-advertisement'. ${ }^{44}$ The petition for special leave to appeal from the judgment of the martial law court was consequently heard on the very day that the men were to be executed, 2 April. Presenting the case, Jellicoe argued that the judgment of the martial law court was wholly illegal. There had never been a state of war or rebellion in the colony which could justify the proclamation of martial law. He also pointed out that the event for which the men were condemned took place before martial law had been proclaimed. In addition, he quoted from McCallum's exchanges with his ministers, now published in a Blue Book, which showed that the civilian courts were open and 'capable of trying these charges'. Jellicoe also had to address the point (raised by Lord Davey) that the application had been brought directly to the Privy Council, rather than to a court in Natal. His reply was that the judicial committee had statutory jurisdiction to determine appeals from any colonial court, and that 'the prerogative of the King in Council was wide enough and strong enough to quash any illegal sentence of death in any of the Colonies.' At the very least, he argued, given the Governor's comments about the possibility of having a civilian trial, there were sufficient prima facie grounds to justify a further investigation. ${ }^{45}$

${ }^{42}$ See e.g. 'Pro-Bambata Party Formed', Daily Mail, 27 April 1906.

43 Ngcukaitobi, The Land Is Ours, pp. 80-82; and David Killingray, 'Significant Black South Africans in Britain before I9I 2', pp. 409-4I6.

44 Governor to Secretary of State, 20 April I906, CO I79/234/I6892, f. 270.

45 Mgomini, Mzinelwa and Wanda (by Their Next Friend Alfred Mangena) v. His Excellency the Governor and the Attorney General for the Colony of Natal (1906) 22 Times Law Reports 4I3. 
The application failed. In giving the judgment of the court, Lord Halsbury did not address the legal arguments made by Jellicoe. He did not consider whether martial law courts had the jurisdiction to try cases committed before its proclamation, ${ }^{46}$ nor whether the judicial committee had its own jurisdiction to consider the matter. ${ }^{47}$ In a oneparagraph judgment Halsbury simply noted both that the government of Natal had felt it necessary to proclaim martial law and that the colonial courts had not been applied to. He ruled that this was not an appeal from a court, 'but in substance [one] from an act of the Executive'. The court did not consider the question of whether the state of affairs in Natal justified martial law, or whether the men had been properly tried. Indeed, the Privy Council seemed in this case to close the door it had appeared to leave open in Marais: to judge whether there was such a state of war or rebellion as necessitated exceptional action. For as Halsbury put it, 'apart from questions as to jurisdiction, any interposition of a judicial character directed with most imperfect knowledge both of the danger that has threatened Natal, and of the facts which came before the tribunal of war, would be inconsistent with their Lordships' duties. ${ }^{48}$ It was an odd comment to make, given that the court was being asked for the executions to be stayed, pending a further hearing in which full arguments might be made, including arguments relating to the dangers facing Natal. At noon on the same day, the men were executed.

While Churchill privately disagreed with Natal's decision to execute the men, he publicly defended the colony's right to do it. Answering critics who questioned the right of martial law courts to deal with offences committed before its proclamation, Churchill stated that 'all martial law is illegal, and an attempt to introduce illegalities into martial law [...] is like attempting to add salt water to the sea.' $\mathrm{He}$ added that ' $[t]$ he only restriction on martial law is that no more force is

${ }^{46}$ Jellicoe cited Charles M. Clode, The Administration of Justice under Martial Law, 2nd ed., 2 vols. (London, John Murray, I874), vol. I, p. I89 for this proposition, which drew on debates following the proclamation in Demerara in I 823 suggesting that martial law courts had no jurisdiction to deal with offences committed before its proclamation (quoted Charles M. Clode, The Military Forces of the Crown, 2 vols. (London, John Murray, I 869), vol. 2, pp. 489-490).

47 Under section 4 of the Judicial Committee Act of 1833 ( $3 \& 4$ Wm. IV c. 4I), the monarch could refer any matter to the committee.

${ }^{48}$ Mgomini and Others v. The Governor of Natal (Natal) [1906] UKPC 22. 
used than is necessary, and where more force is used than necessary persons may afterwards be called to account unless covered by an Act of Indemnity.' ${ }^{49}$ Churchill's exposition of the law drew sharp comment from Frederick Pollock. In a letter to The Times, Pollock took issue with the implication that an act of indemnity might be required to validate acts which could never be justified by the general law. Reminding readers of the Diceyan view, he pointed out that 'the use of an Act of Indemnity is not to condone acts that were absolutely illegal, but to cover the inevitable margin of doubtful cases and honest errors of judgment. ${ }^{5 \circ}$ At the same time, Pollock also rejected Jellicoe's suggestion that the powers of the military under martial law derived from any proclamation, reiterating the common lawyers' view that such a proclamation was nothing more than a statement by the executive of its view that conditions were such that it was necessary to use extraordinary measures. ${ }^{5 \mathrm{I}}$ But this did not seem to be the view of the government of Natal, nor (in effect) of the Colonial Office. For by this stage - with the colony evidently at peace - martial law was being maintained in Natal for the sole reason that its parliament could not pass an indemnity act until May. Although Churchill thought that 'the mere want of an Act of Indemnity ought not in itself to justify prolongation of such a harsh \& objectionable system', Fred Graham answered that it had to be maintained 'because in the interval between martial law $\&$ the Act of Indemnity the Governor \& others might be indicted for murder'. ${ }^{52}$ This seemed to indicate both that officials in London felt that a kind of 'state of siege' granting legal immunity remained in place so long as the proclamation of martial law was not withdrawn, and that they had little confidence that a justification of necessity could be pleaded.

The question of the Governor's potential liability soon became more pressing, when Mangena and Jellicoe commenced criminal proceedings in London against McCallum. Mangena was proving to be something of a thorn in the government's side, having also petitioned parliament for an inquiry into the disturbances in Natal at

\footnotetext{
49 Parl. Debs., 4th ser., vol. I 55, col. 273 (2 April 1906). See also Hyam, Elgin and Churchill at the Colonial Office, pp. 242-243.

50 The Times, 5 April I906, p. 8.

${ }_{51}$ See also the letter of T. E. Holland in The Times, 5 April I906, p. 8.

${ }^{52}$ Note, 7 April 1906, CO I79/233/I I 28 I, f. 307.
} 
the end of April. ${ }^{53}$ The prosecution was brought under two acts: one passed in 1698 to allow for the prosecution in England of Governors who committed crimes overseas, and one passed in 1802 to allow those holding public employments abroad to be tried in England. ${ }^{54}$ Two famous governors Governors of Jamaica - Joseph Wall and E. J. Eyre - had been prosecuted under this law, the former being executed, the latter escaping trial when no true bill was found by the jury. Lawyers at the Colonial Office were keenly aware of the danger posed by this unrepealed law. In Cox's view, for the Governor of a responsible government colony which had proclaimed martial law to be prosecuted under such legislation would have disastrous effects on the empire. Since no indemnity act passed in Natal would have any effect outside the colony, he thought that the only chance for the Governor to escape trial would be if a grand jury rejected the bill, or if the Attorney General entered a nolle prosequi. The Attorney General confirmed Cox's view of the law, but noted that no criminal proceedings could be taken in England so long as the Governor remained in Natal. ${ }^{55}$ McCallum was advised accordingly.

The news of Mangena's action troubled the Governor. 'The natives are watching the newspapers very closely', McCallum told the Secretary of State, Elgin, 'and did they know of the threatened proceedings my authority over them as Supreme Chief would be much weakened.' He also thought that the legislation in question, passed 'in the very early days of colonial administration', should not apply to a colony with a responsible government. ${ }^{56}$ In the third week of May, Jellicoe and Colenso laid formal charges of homicide against McCallum in the Bow Street magistrates court, though (as officials had predicted), the proceedings ran into the ground in the absence of

53 Manchester Guardian, 27 April 1906.

${ }^{54}$ I I Wm. III c. I 2, 42 Geo. III c. 85 . As A. B. Keith noted, the I 86I Offences against the Person Act section 9 also gave English courts jurisdiction over murder committed anywhere. Minute, I4 April I906, CO I79/239/I2835, f. 383 .

55 Opinion of John L. Walton, 24 April 1906, CO 885/I6, No. 3I. W. F. Finlason had argued that a governor would be protected by an indemnity act: Commentaries upon Martial Law (London, Stevens and Sons, 1867), p. 268, and it had been held in Phillips v. Eyre (1869) LR 4 QB 229 that an indemnity act protected from tort liability.

${ }^{56}$ McCallum to Elgin, 27 April I906, CO 879/234/r80 Io, f. 363. 
the potential defendant. ${ }^{57}$ In the middle of these proceedings, the Colonial Office pondered whether to change the law allowing such prosecutions, but decided against it, since any such move this point would only draw attention to the government's liability. ${ }^{58}$ Steps were taken, however, to find out more about Mangena in South Africa in order to discredit him. ${ }^{59}$ Material about Mangena - which suggested that he was not originally from Natal and had defrauded a group of Africans in Cape Town - was sent to London in the middle of June, and published in a Blue Book. Graham commented, 'We shall probably have no further trouble from him. ${ }^{60}$

\section{Martial Law after Bambatha's Uprising, April-September 1906}

\section{Martial Law Trials of the Rebels}

Any doubts that the Colonial Office had about the continuation of martial law at the time of the execution of the twelve accused of killing Hunt and Armstrong were extinguished by Bambatha's revolt. The revival of unrest saw another tranche of trials by courts martial, as well as a much larger stream of cases tried by magistrates. The Natal authorities were keen to try the rebels as quickly as possible in the locations where they had rebelled. Whereas many of the trials during the first phase had been for acts of defiance to the magistracy, and for marching with arms, many of those tried subsequently had been caught in acts of rebellion. The ambush of white policemen on the road to Keate's Drift on 4 April by followers of Bambatha, which left three dead, led to two major martial law trials at Greytown. The first case (which began on 23 June) did not result in any convictions for the murder, but twenty-one men were convicted of public violence and treason. ${ }^{6 \mathrm{I}}$ Seventeen more were charged in early August at a second

57 Manchester Guardian, I6 May I906, 22 May I906.

$5^{8}$ As Churchill put it, 'Leave well alone': CO I79/234/I80 Io, f. 362.

59 CO 879/92/26, No. I7, p. 20.

60 Note, 2I June I906, CO I79/235/2I 724, f. 350 . The material was published in July in PP I906 (Cd. 3027), No.95, p. 95. It was reprinted in several newspapers, which were later sued by Mangena: see Mangena v. Edward Lloyd Ltd (r908) 98 LT 640; Mangena v. Wright [I909] 2 KB 958; 'Papers Relating to the Case of Mr Alfred Mangena', PP I908 (Cd. 4403) LXXII. 8I9; and Ngcukaitobi, The Land Is Ours, pp. 93-97.

6r PP I906 (Cd. 3247) LXXIX. 687, No. 23, p. I7. 
trial, in a court presided over by Lt-Col. Bousfield, 'one of [the] leading lawyers of Durban'.62 They too were acquitted of the murder, but were convicted of other charges. The beginning of July also saw three of Bambatha's principal indunas tried at Greytown for public violence and treason, though only one was convicted. A number of trials at Nkandhla in June, July and August dealt with Sigananda and his followers. Sigananda himself surrendered on I3 June. Plans were immediately made for the trial of this chief and his sons, which took place two weeks after his capture. ${ }^{63}$ Thirteen more of his indunas and headmen were tried at Nkandhla in August. Sigananda died before sentencing, but four other men tried at Nkandhla - including his son and commander in chief Ndabaningi - were given death sentences, later commuted to life imprisonment. The rebel leaders Ndhlovu and Meseni were tried by court martial in Mapumulo for high treason and murder in the middle of July, very shortly after their capture. Their trial was presided over by another Durban lawyer, Lt-Col. Wylie, who had also presided at Sigananda's trial. ${ }^{64}$ They were also sentenced to death by the court.

All of these trials took place after the rebellion had effectively been crushed at Mome Gorge. Although the Governor thought that the rebels could be tried in civilian courts, ${ }^{65}$ he again came under pressure both from ministers and from the military, who insisted that 'Natives cannot understand the necessity for, or wisdom of, resorting to what they consider the tedious and protracted procedure of the Civil Courts in cases of this nature. ${ }^{66}$ He therefore agreed to the continuation of courts martial, with the proviso that 'magnanimity should be exercised.' The death sentences imposed on the men tried at Nkandhla were commuted, ${ }^{67}$ as were those imposed on Meseni and Ndhlovu, since McCallum was not convinced that there was sufficient evidence to connect the chiefs directly with the murders. ${ }^{68}$

${ }^{62}$ PP 1906 (Cd. 3247), No. 38 , p. 53.

${ }^{63}$ CO 879/106/I, No. 494, p. I77; No. 5 I I, p. I83; No. 560, p. 199. See also PP 1906 (Cd. 3027 ), enc. 3 in No. 97, p. 100.

${ }^{6}$ PP 1906 (Cd. 3247) No. 33, p. 34. See further Guy, The Maphumulo Uprising, pp. III-I 28.

65 PP 1906 (Cd. 3247), enc. I in No. 26, p. I 8.

${ }^{66}$ PP 1906 (Cd. 3247), enc. 2 in No. 26, p. I9. ${ }_{67}^{6 P}$ PP 1906 (Cd. 3247), No. 57, p. 86.

${ }^{68}$ PP I906 (Cd. 3247), No. 38, p. 53. At the same time, many sentences of long periods of imprisonment as well as lashings were confirmed by the Governor. 
McCallum's concern that martial law trials should follow the principles of legality as closely as possible became apparent when he reviewed the case of Madamu kaMbaupanzim who had been convicted of spying on 4 May by a court martial of three officers, and sentenced to death. As soon as the trial began, his counsel objected that the court was improperly constituted, since it did not have five members, as required under military law. Having read the transcript of the twoday trial, McCallum was far from convinced of Madamu's guilt. More importantly, he considered that the court had been improperly constituted and that the conviction should be quashed, while leaving open the possibility of trying him before the civil courts. ${ }^{69}$ Ministers protested at this, and referred the question to Natal's Attorney General, G. A. de Roquefeuil Labistour, who felt both that the evidence justified the conviction, and that there were no binding rules as to the constitution of a martial law court. ${ }^{70}$ Officials in London sided with Labistour, Cox minuting that the Governor was confusing martial law - which was the mere will of the commander - with military law. 'I cannot say that I find anything to show that the man had not a fair trial', he noted, 'He was able to X examine $\&$ to give evidence on his own behalf $\&$ he had an advocate to defend him. ${ }^{71}$ Elgin consequently turned down McCallum's request for the matter to be referred to the Law Officers in London, telling him to decide the punishment on the merits of the case. The sentence was duly commuted to five years' imprisonment with hard labour. ${ }^{72}$

McCallum and his ministers also disagreed over whether the remaining suspects for Hunt's murder - including Mjongo - should be tried by civilian or martial law courts. ${ }^{73}$ On this occasion, his view prevailed. Their trial began in the Supreme Court a little over a week after the end of the Nkandhla court-martial trials of Sigananda's indunas, with martial law still in place. The men were convicted, and McCallum congratulated himself that a civilian court had convicted these men on similar evidence to that given to the court martial. ${ }^{74}$ Having been nursed back to health after their capture, the men were

\footnotetext{
69 Minute by H. McCallum, I I June I906, CO I79/236/3063 I, f. 334.

70 Minute, I9 June I906, CO I79/236/3063 I, f. 339.

${ }^{71}$ Minute, 25 August I906, CO I79/236/3063I, f. 3 I 5.

${ }_{72}$ CO 879/92/26, No. 32, p. 42; PP 1906 (Cd. 3247), No. 58, p. 87.

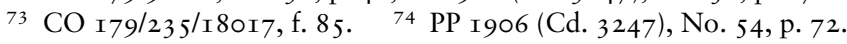


now sentenced to death. ${ }^{75}$ Frank Colenso petitioned Elgin to spare them, but it was decided not to interfere, and they were executed on the following day. ${ }^{76}$

\section{Tilonko’s Trial}

It was during this second, more violent phase of the rebellion that what would be the most controversial trial under martial law took place. This was the trial of Tilonko, whose followers had brandished spears in defiance of authority, in ways similar to the followers of the chiefs who had not been tried, Ngobizembe, Miskofeli and Charlie Fynn. Unlike those tried at Greytown, Nkandhla and Maphumulo, Tilonko had not been a rebel in the field. He was, however, suspected of planning the rebellion. According to McKenzie's intelligence officer, Lt-Col. Henry Lugg, Tilonko had conspired with others (including Miskofeli's induna, Mamba) to resist the poll tax, and it had only been 'the drastic measures' taken by the military which had prevented the whole country becoming 'ablaze with rebellion'. ${ }^{77}$ The authorities were also suspicious about two emissaries Tilonko had apparently sent to the Zulu king Dinuzulu. With the promulgation of the poll tax, rumours had begun to circulate that Dinuzulu had ordered Africans to kill all white animals - goats, pigs and fowl - and to destroy European tools. The Natal authorities remained uncertain of Dinuzulu's role in the rebellion: although he would be tried by a civilian Special Court in Greytown for treason in the following year, they had no specific information against him in the middle of $1906 .^{78}$

Despite their suspicions about Tilonko, the authorities did not appear to regard him as a dangerous rebel. ${ }^{79}$ It was only after Tilonko had failed satisfactorily to explain his conduct to the Minister of Native Affairs, H. D. Winter, when summoned to Pietermaritzburg on 23 July, that the decision was taken to charge him with sedition and public violence. Even then, he was allowed to return to his tribe, and was

75 PP I906 (Cd. 3247), No. 60, p. 90.

${ }^{76}$ Letter from Francis Colenso to Secretary of State, 7 October I906, CO I79/239/ 37069 , f. I 85 .

77 CO 879/92/26, enc. I in No. 5, p. 6.

${ }^{78}$ For his trial, see Marks, Reluctant Rebellion, chs. IO-I I.

79 PP I906 (Cd. 3247), No. 33, p. 34. 
trusted to appear for his trial. ${ }^{80}$ The trial itself commenced on $30 \mathrm{July}$, just as the order to demobilise the active militia had been given, ${ }^{81}$ with the Governor confident enough to tell the troops at a parade in Pietermaritzburg that 'in the moment of our success it is right that what we have done already should be allowed to sink deeply into the natives, and that we should show them as much mercy as possible. ${ }^{82}$ The trial was held behind closed doors, since the authorities wanted to prevent the evidence of emissaries being sent to Dinuzulu from being reported. As a result of this, Tilonko's strong supporter Harriette Colenso described by McCallum as a woman of 'pronounced negrophile tendencies ${ }^{83}$ - was excluded from the courtroom. His lawyer, Eugene Renaud, opened his case by objecting that his client - who had not been captured in the field - should be tried in a civilian court. ${ }^{84}$ The objection was summarily dismissed, but Tilonko's supporters brought it to the attention of Ramsay MacDonald, who on the following day reminded Churchill in the House of Commons of his earlier statement that 'only natives caught in the act of fighting are to be tried by court-martial. ${ }^{85} \mathrm{In}$ response, the Colonial Office referred the matter to McCallum, who replied that the policy of only trying rebels caught in the field had been abandoned at the start of May. ${ }^{86}$

Much of the evidence at the trial focused on the fact that, in the days after Hunt's murder, Tilonko's tribesmen had armed themselves and had marched in large numbers, both in daylight and during the night. White witnesses spoke of a change in behaviour among the Africans since the previous August - 'They have been very cheeky lately' ${ }^{87}$ - and how, around IO-I I February, men carrying spears had used much more threatening language. This had struck fear into the whites, who had gone into laager at Richmond. Numerous African witnesses gave evidence that they had been told to arm, with many stating that this was to be done to protect Tilonko, who it was feared was going to be

80 PP I906 (Cd. 3247), No. 37, p. 37.

${ }^{8 \text { I }}$ CO 879/I06/I, No. 69I, p. 243; PP I906 (Cd. 3247), No. 39, p. 53.

82 Natal Witness, 3 August I906.

$8_{3}$ Governor to Secretary of State, Io November I906, CO I79/237/44576, f. 288.

84 'Verbatim Note of Proceedings in re Tilonko', CO/I 79/237/44576, f. 366.

85 Parl. Debs., 4th ser., vol. I62, col. 702 (3 I July I906).

86 PP I906 (Cd. 3247), No. 25, p. I7.

87 Evidence of R. W. Newbold, 'Verbatim Note of Proceedings', CO/I79/237/44576, f. 450 . 
arrested. There was no direct evidence provided by any of the witnesses in the courtroom that Tilonko himself had given the order to arm. Rather, the orders appeared to have come from his indunas.

One witness, Sancubu, had, however, given a statement to Lt-Col. Lugg, which seemed to incriminate the chief. According to the statement,

TILONKO asked me if I had delivered the message which he had sent to me to tell the people to arm ... I heard that Chief DINIZULU was to send an 'UMLUNGO,88 which would overpower the Whites and their adherents and cause their guns to belch forth water instead of fire, and to disable them that we would be able to kill them with our sticks. DINIZULU was bringing an Umlungo also an Impi to assist us against the Whites. I heard of Msutu and Mqaikana [the messengers] being sent to DINIZULU all chiefs were combined to resist the Poll-tax and fight the white man. ... A black bull was to appear from the North which would fly along and destroy everything in its road. There would have been a general rising in my opinion had the White man not been ready. ${ }^{89}$

At the trial, however, Sancubu denied making these allegations, and claimed only to have signed the document (which had already been prepared) when he was threatened with being tied to a pole up all day in the sun, as other witnesses had been. Renaud objected that, since the witness was discredited out of his own mouth, his statement could be of no evidentiary value. Nonetheless, the prosecutor recalled Lugg and the translator to testify that he had made the statement freely, and the statement was itself appended to the transcript of the trial, as part of the evidence against Tilonko. However inadmissible in an ordinary court, it clearly played a key role in Tilonko's conviction. Evidence was also given by the two emissaries to Dinuzulu, Msutu and Mqaikane. Mqaikane, the tribe's witness who dealt with Dinuzulu, denied claims made by Msutu (his cook and helper, who had run away after two days) that they had been sent to ask for assistance to fight. In any event, the evidence was clear that Dinuzulu favoured their paying the tax, and that by the time they returned home, there was no talk of fighting.

Tilonko's defence appeared in many ways similar to the arguments which had exonerated Miskofeli and Charlie Fynn in the eyes of the authorities. He claimed that he himself favoured payment of the tax,

${ }^{88}$ This is probably a mis-transcription of the Zulu word 'umlingo', meaning 'magic' rather than 'umlungu', meaning a 'white person'.

89 'Verbatim Note of Proceedings', CO/I 79/237/44576, ff. 6I 6-6I 7. 
though the tribe was against it. Since the tax was not legally due before the end of May, he had done no wrong in failing to pay when the magistrate came to collect it in February. He denied instructing the tribe to arm, claiming that he had little control over the indunas, and he said that he had gone into hiding from fear of being arrested. Although, in the case of Charlie Fynn, the authorities appeared to accept that tribesmen could arm without being ordered by their chief, and that they might do so in order to protect their chief, such arguments were rejected in Tilonko's case. Although the accusation that Tilonko had ordered his men to arm rested largely on conjecture and hearsay evidence rather than the kind of concrete proof which would satisfy a civilian court, he was convicted by the court, and sentenced on I7 August to ten years' imprisonment with hard labour, together with a fine of cattle. Confirming the prison sentence, McCallum commented that the Attorney General had informed him that the 'greatest possible care' had been exercised in the trial 'and that no civil tribunal could have done better'.$^{90}$ In fact, his trial would prove to be much more controversial than the Governor assumed, for it raised a host of questions about the nature of martial law, which would continue to be debated in legal and political circles for some months to come. These questions were further complicated by the manner in which Natal passed its Indemnity Act.

\section{Natal's Indemnity Act, the Privy Council and the Rule of Law}

\section{The Indemnity Act I 906}

If great political care had been taken in the Cape to ensure that sentences imposed under martial law on white rebels had been just and proportionate, the same cannot be said of Natal's approach when dealing with black rebels in I906. For Natal's parliament passed the measure before many of the trials had even begun, requesting the Governor to withhold his assent until such a moment when those trials had ended and martial law could be lifted. As officials in London perceived, this was to treat martial law as if it were a continental-style state of siege.

90 PP 1906 (Cd. 3247), No. 38 , p. 53. 
The Indemnity Bill which came to Natal's parliament in June 1906 contained no provision for the revision of sentences. It was also radically innovative in one crucial respect. Section 9 of the bill provided for 'future measures for suppression of disturbances and punishment of offenders', giving the Governor the power to punish any rebel by court martial (including by death) during the continuance of the rebellion. ${ }^{9 \mathrm{I}}$ It abandoned any idea that the legislature should review sentences before confirming them. Opponents of the measure in the Natal Assembly spoke of it as giving the government a blank cheque. ${ }^{92}$ Officials at the Colonial Office were also unimpressed. ${ }^{93}$ In R. V. Vernon's view, the clause 'empowers the Governor to set up practically a "state of siege" and went against the 'recognised principles' on which indemnity acts were passed. ${ }^{94}$ H. C. M. Lambert noted that the clause had been borrowed from legislation passed after the Union 'for the suppression of rebellion in Ireland', ${ }^{95}$ and noted that other colonies (such as Jamaica in I 845$)^{96}$ had passed similar legislation to establish a state of siege: 'But there is no modern precedent for such legislation, which is in effect the suspension of the constitution or at least of the fundamental rights of the subjects which depend for their enforcement on the Courts. ${ }^{97}$ This was not simply an abstract question for the Colonial Office: for Ramsay MacDonald had tabled

9I A copy of the act is in PP 1906 (Cd. 3247), enc. I in No. 63, p. 92.

92 Times of Natal, 28 June 1906.

93 Cox assumed that the 'future indemnity' clause had been motivated by Mangena's proceedings in Bow Street, which R. V. Vernon thought reflected a 'remarkable confusion of thought' on the part of Natal's Minister of Justice. CO I79/235/ 26687 , f. 493.

94 Minute dated I3 July I906, CO I79/238/25217, f. 249.

95 An Act for the Suppression of Rebellion in Ireland, 43 Geo. III c. I I 7. This re-enacted earlier Irish legislation which had spoken of 'His Majesty's undoubted prerogative in executing Martial Law', which some commentators took as proving the right of the crown to proclaim martial law. See Clode, Military Forces of the Crown, vol. II, pp. I70-I 74 .

${ }^{6}$ Jamaica's 9. Vic. c. 35 (An Act to consolidate and amend the Militia Laws), sections 96-97 gave the Governor power to proclaim martial law on the advice of a council of war, and (section I I I) allowed those sued for acts done during martial law to plead the general issue and give evidence of the 'special matter'. In February I 866, the Law Officers (Roundell Palmer and R. P. Collier) advised that, under this act, the Governor could not be prosecuted for proclaiming martial law without necessity, and military officers were not liable for exceeding the necessity of the case, provided they acted bona fide: $\mathrm{CO} 885 / 3 / 17$, p. 33 .

97 Minute dated I4 July I906, CO I79/238/25217, f. 246. 
a question on the matter in the Commons, and officials were aware of English eyes watching the government's reaction.

Once again, there were imperial complications. Characteristically overlooking His Majesty's African subjects, the permanent undersecretary of state Sir Montagu Ommanney noted that, 'If this particular community of British subjects likes to forego its fundamental rights in order that its officials $\&$ the officers $\&$ men of its local forces shall not be exposed to vexatious actions under the ordinary law, I can't see why we should interfere.' But Cox was more concerned by imperial interests. In his view, the bill gave the Governor dictatorial powers to act without any restraint even by his ministers. For him, the question was not whether the colony wanted it or not, but whether an imperial officer should be given such powers, in effect shifting the responsibility for the use of such brute force 'from ministerial shoulders onto HMGovt'..$^{98}$ After the bill had passed through Natal's assembly and Legislative Council, Elgin sent a telegram to the Governor, pointing out the undesirability of prospective legislation, since the prospect of needing to pass an indemnity measure provided 'a useful check on the operation of martial law', and asking ministers to consider following the Boer war precedents. ${ }^{99}$

McCallum's ministers held firm. Attorney General Labistour was of the view that Natal was perfectly within its rights to pass such a measure, adding that the Governor would be expected to use his powers in a 'constitutional' way, on the advice of his ministers. Natal clearly regarded this as a local matter. ${ }^{100}$ Furthermore, given that ministers still wanted martial law in place - to allow the trials of the remaining rebel leaders - McCallum pointed out that, if this bill were not passed, it would have to be prolonged until Natal's parliament met again in nine months' time. ${ }^{\text {IOI }}$ Although Cox protested that this meant that life and property were 'to be endangered to suit the convenience of legislators', officials in London began to concede the argument,

${ }_{98}$ Minutes, I4-I6 Julyi906, CO I79/238/25217, ff. 246-248.

99 CO 879/106/I, No. 636, p. 225.

roo McCallum did not consider that the bill fell within the classes of reserved legislation listed in the Royal Instructions of I893: PP I906 (Cd. 3247), No. 29, p. 28; No. 34, p. 36. On the Instructions, see A. B. Keith, Responsible Government in the Dominions, 3 vols. (Oxford, Clarendon Press, I9I 2), vol. 2, p. IOI4.

ror $\mathrm{CO} 879 /$ I06/I, No. 695, p. 245. 
admitting both that the colony had the power to pass such legislation on the Jamaica precedent - and that the Governor would be expected to act on ministerial advice. To avoid 'throw[ing] down the gauntlet to Natal', officials suggested asking Natal to end martial law 'at an early date'. ${ }^{102}$ McCallum took the view that it was unnecessary to insist on the amendment of the measure, since the disturbances were practically over by early August, and martial law would soon be ended. ${ }^{103}$ In the event, he delayed assenting to the measure until martial law was ended on I October.

\section{Tilonko's Challenges and the Privy Council}

In the meantime, Alfred Mangena submitted a petition to the King in Council, which recited that the Governor had 'grievously and illegally oppressed divers loyal and dutiful subjects' by imposing martial law, and which requested the King to refer the matter to a committee of the Privy Council, to investigate and advise disallowance of the indemnity bill. ${ }^{\mathrm{IO}}$ This unorthodox petition provoked much discussion in Whitehall. Although officials thought that it was a political matter which did not concern the judicial committee, they were aware that, under section 4 of the Privy Council Act of I 833, there was a power to refer such questions to that committee. They concluded that the best way to proceed was to pass it on pro forma to the Council Office with an explanatory note, setting out that Lord Elgin proposed advising the king not to disallow the measure. As the legal assistant J. S. Risley pointed out to his colleagues, where the recommendation was against a petition, 'the matter never comes before the Council at all but the petition is "squelched" in the Council Office.'

Having failed in this attempt, Tilonko's supporters entered a supplementary petition, invoking the Natal Constitution Act I893 which empowered the crown by Order in Council to disallow legislation which had been assented to by the Governor. ${ }^{\text {I06 }}$ Once more officials sought to put bureaucratic obstacles in the way. In the face of the

\footnotetext{
${ }^{102}$ Note by Ommanney, 2 August I906, CO I79/236/28242, f. 372.

103 PP I906 (Cd. 3247), No. 28, p. 28.

ro4 The petition is in $\mathrm{CO} I 79 / 238 / 33 \mathrm{II}_{7}$, ff. $29-48$.

ro5 Minute dated 24 September I906, CO I79/238/33 I I7, f. 23.

Iо6 'The Humble Petition of Tilonko', CO I79/239/3843 I, f. 262.
} 
Colonial Office's insistence that the question of disallowance was one for Elgin to advise on - and its further insistence that he would not advise disallowance - Tilonko's lawyers countered that the Secretary of State was thereby usurping the Privy Council's power. ${ }^{107}$ With continued pressure from Tilonko's solicitors, as well as from friendly MPs, the Colonial Office felt constrained to follow constitutional procedure to the letter, with Elgin formally submitting Tilonko's petitions to the king and advising against disallowance. ${ }^{\text {I }} 8$

This was not the only legal strategy deployed to secure his freedom. At the end of August, Tilonko petitioned the Supreme Court of Natal for his release. ${ }^{\text {I09 }}$ During the argument, the two differing views of the nature of martial law were put forward. Drawing both on Marais and on Mgomini, Attorney General Labistour argued that the court had no jurisdiction while martial law was in force. A declaration of martial law, like a declaration of war, was in his view conclusive for the court. Renaud, however, insisted that the court had the right to consider whether a state of war existed and to determine whether Tilonko was being legally confined. Although Labistour insisted on precedents which showed 'that your Lordships will not interfere with the decision of the Executive or the Governor for the simple reason that you have not the power to carry it into effect', ${ }^{\text {I }}{ }^{\circ}$ the judges were not wholly convinced. 'Suppose that one could conceive of an absolutely misguided Executive as to declare Martial Law in a time of peace', Justice Dove-Wilson asked, 'would the civil court be debarred from saying that Martial Law was illegally declared?' ${ }^{\text {II }}$ In the end the court was divided, with the majority taking the more liberal position that a mere declaration of martial law did not oust the jurisdiction of the court. However, they decided to give the Attorney General more time to provide evidence of the necessity for martial law. If this was a significant assertion by the court of its authority, it was to serve

${ }^{107}$ See letters from Helder, Roberts, Walton \& Giles Solicitors to Churchill, 26 November and 7 December 1906 in CO I79/239/43630, f. 279; CO I79/239/ 45 I 56, f. 284.

ro8 This was to avoid any possibility of the secretary of state being sued in tort for failure to present the petition: see Irwin v. Grey (I 862) 3 F. \& F. 635 .

ro9 In re Tilonko (1906) 27 Natal Law Reports 567; a full transcript is in CO I79/237/ 44376, ff. 310-36r.

по In re Tilonko, CO I79/237/44376, f. 336.

${ }^{11}$ In re Tilonko, CO $\mathrm{I} 79 / 237 / 44376$, f. 333. 
little purpose, for, having waited for the decision which enunciated the principles he wished to see established, Renaud dropped the proceedings, in light of Labistour's comments to the court that an act of indemnity had been assented to, though not yet published.

In fact, Labistour's remarks had been misleading. The fact that Elgin had approved the Governor's assenting to the measure did not mean that the crown's assent had been formally given: indeed, the requisite assent would not be given for another month. This meant that Tilonko's incarceration had not yet been rendered lawful by statute. When the papers were sent to London, together with a new petition from Tilonko for the crown to exercise its prerogative of mercy, concerns were raised at the Colonial Office about Labistour's misstatement. 'I do not think we can ignore the point raised in this minute', Vernon noted, 'though Tilonko's friends have failed to take it.' While his colleagues agreed that the judges were right to assert their jurisdiction, ${ }^{\mathrm{II} 2}$ they felt that it had made no difference to Tilonko. In Lambert's view, 'even if the Court had ordered the release the Govt could have proceeded further against $\mathrm{T}$ under martial law $\&$ their acts would have been validated if not the original proceedings.' In Cox's view, the military would simply have ignored the order and later been justified by the indemnity. These observations - which were hardly an endorsement of the rule of law overlooked the fact that what was at stake was not just Tilonko's incarceration, but his ten-year sentence. Given the controversy caused by London's earlier attempts to intercede to spare the Richmond convicts, there was little appetite to interfere now. This was all the more so since McCallum had made it clear he expected no sympathy for Tilonko, who 'appears to forget that rebellion is one of the worst crimes of which a native can be guilty'. ${ }^{\mathrm{II} 3}$

While still pursuing his petition to disallow the Indemnity Act, on I7 October, Tilonko's supporters petitioned the Privy Council in its judicial capacity, for special leave to appeal from the decision of the

${ }^{\text {II2 }}$ CO I79/237/44376, f. 28I. As Lambert explained, 'otherwise a proclamation of Martial Law in February if not withdrawn would remain ipso facto a bar to judicial proceedings in August or indeed indefinitely, a theory which may indeed be recognised in the continental "state of siege", but which our Courts have never accepted.'

${ }^{113}$ Under Zulu law, he added, rebels and their entire families were 'exterminated' and their homesteads laid waste. Governor to Secretary of State, Io November I906, CO I79/237/44576, f. 288. 
martial law court. The case was argued on 2 November, when Jellicoe argued that Tilonko had never taken up arms against the Government, that Natal had not been in a state of war, that the civil courts were open, and that his trial before the martial law court was therefore without jurisdiction. In contrast to the proceedings in Mgomini and Others v. The Governor of Natal, on this occasion the judges in the judicial committee did not doubt their jurisdiction to hear a case brought directly before them from a Natal martial law court. Furthermore, Lord Halsbury took the opportunity briefly to address questions of law which he had left aside in the earlier case. Martial law was not 'law' at all, he declared, but 'the right to administer force against force in actual war'. Echoing the comments of Pollock on the earlier case, he noted that its existence did not depend on a proclamation, but on the factual 'question whether there is war or not'. Halsbury now conceded that there might 'be a question of doubt' about whether such a state of war existed, which 'might have required consideration' by the court - a view of the law which might have given the Richmond prisoners a reprieve had he turned his mind to it in April. However, in this case, Halsbury concluded, there was nothing for the court to discuss, since Natal's parliament had already passed an Indemnity Act which provided that the sentences of martial law courts should be deemed valid. 'The only thing for persons who are subject to such an Act of Parliament to do is to obey.' ${ }^{\text {II } 4}$

This was not the end of Tilonko's appeals against his sentence. In April 1907, habeas corpus proceedings were brought once more in Pietermaritzburg to secure his liberation. Although the application was dismissed after Labistour put in a document certifying that Tilonko's sentence came within the Indemnity Act, ${ }^{115}$ the case provided another opportunity to seek special leave to appeal to the Privy Council. On this occasion, Jellicoe came prepared with arguments to dislodge the Indemnity Act. They rested on the fact that Natal's parliament had been

${ }^{114}$ Tilonko v. Attorney General of the Colony of Natal [1907] AC 93 at 95. In Responsible Government (vol. I, p. 272), A. B. Keith stated that the principles relating to martial law were 'admirably laid down' in this judgment; but in a later work, he read the case as extending the principle of Marais - that courts could not interfere with the actions of the military in time of war - to times of rebellion: $A n$ Introduction to British Constitutional Law (Oxford, Clarendon Press, I93 I), p. 73.

${ }^{115}$ In re Tilonko (1907) 28 Natal Law Reports 190. 
dissolved on 5 August, a month and a half before the Governor had assented to the bill. In order for the legislation to be valid, Jellicoe argued, it had to be passed by the concurrence of the whole legislature, which was not possible if the Assembly and Legislative Council had been dissolved before the Act had been passed. He added that to suggest that assent to legislation could be withheld after the dissolution for any indefinite period 'in order to validate subsequent illegal transactions or to destroy rights which vested after the dissolution of Parliament was a libel upon the Sovereign and the Constitution'. ${ }^{116}$ For good measure, he added an argument that the act, which prejudiced the royal prerogative - by denying the prerogative writ of habeas corpus - was repugnant to the law of England and against common right and reason.

Similar arguments had already been made in a petition submitted on Tilonko's behalf to the House of Commons. In this petition, Tilonko had complained that Natal's ex post facto Indemnity Act had legalised the unlawful proceedings of an illegal tribunal, and that it was repugnant to Magna Carta. ${ }^{I 17}$ Having read the petition, Churchill could not see how Tilonko's treatment could be defended if it were raised in the Commons, adding 'It is a hateful business.' His officials were less troubled, however, Cox noting that ex post facto legislation was essential where martial law was proclaimed and that its passage proved the necessity for it. Lambert commented, 'Tilonko's legal learning is so extensive and so amazingly incorrect that I think he must have derived it from Mr Jellicoe. ${ }^{\text {II } 8}$ Nor did the arguments cut much ice with the Judicial Committee of the Privy Council. In a judgment even briefer than its earlier one, the court, through the voice of the new Lord Chancellor, Loreburn, said the matter was settled by Natal's Indemnity Act, whose policy or expediency the court had no power to consider. ${ }^{\text {II }}$ The way was thus paved for Tilonko, and the other martial law convicts, to serve out their sentences. But before this could be done, there were further legal problems to encounter.

${ }^{116}$ Tilonko v. Attorney General of Natal (1907) 23 TLR 668 at 669. See also The Times, 6 July I907, p. II.

${ }^{117}$ The petition dated I March 1907 is in CO I79/243/I2449, f. 546. Parl. Debs., 4th ser., vol. I6I, col. I452 (25 March I907).

${ }_{11} 8$ Minutes I I April I907, CO I79/243/I2449, f. 545.

II Tilonko v. Attorney General of the Colony of Natal [1907] AC 46I. 


\section{Tilonko's Deportation}

\section{Removing the Ringleaders}

As early as May I906, Natal's ministers were clear that the ringleaders tried by martial law courts should be removed from the colony. ${ }^{\text {I2O }}$ They were to include not only the rebel leaders tried at Greytown, Nkandhla and Maphumulo, but also Tilonko. The initial plan was to deport them to the Seychelles, which McCallum felt would have 'farreaching effects as a deterrent'. ${ }^{\text {III }}$ Although London's response was unenthusiastic, with officials seeing numerous legal obstacles to this attempt to export martial law, ${ }^{\mathrm{I} 22}$ ministers continued to explore the possibilities of deportation. Towards the end of August, they received offers to take the leaders both from St Helena and from the Cape. Neither was accepted: for St Helena, which had no accommodation for convicts, could take only political prisoners, a status Natal's government was determined to deny these men; while the Cape's offer to put the men to work at East London Harbour initially seemed too expensive. ${ }^{\mathrm{I} 23}$

The question of what to do with the ringleaders became more pressing in January, after the government - having found no solution to the problem of what to do with the large numbers of rank and file rebels still in prison - released $\mathrm{I} 78$ elderly rebels in a way which revived concerns about the prospect of renewed rebellion. For, rather than being sent to distant places, as had been intended, they were inadvertently allowed to return to their homes, where rumours began to proliferate that the king wanted to free all rebels and compensate them. Fearing renewed unrest, Natal's government resolved to stop the releases, and to remove the ringleaders from proximity to those they might influence. For Natal, the matter of deporting these dangerous chiefs was now a matter of priority. The idea of taking up the Cape's offer was finally abandoned, since 'they would still be in touch with

I20 Only twenty-five of the 4,I92 rebels sentenced to periods of imprisonment by December 1906 were so removed: the large majority were sentenced by magistrates to lesser periods of imprisonment: CO 879/I06/I, No. I099, p. 409.

${ }_{\text {I2I }}$ CO $879 / 92 / 26$, No. 6, p. II. I22 CO $879 / 92 / 26$, No. I4, p. I7.

${ }^{123}$ CO 879/92/26, No. 49, p. 57. 
native community' there. ${ }^{\mathrm{I} 24}$ Instead, McCallum secured the agreement of the Governor of Mauritius. ${ }^{25}$

The government of Natal wanted the men to be removed under the Colonial Prisoners Removal Act of 1884 , which could now be done, given that their martial law sentences had been legalised by the Indemnity Act. However, ministers in London were uncomfortable with the proposal that the chiefs should be removed as ordinary criminals. Churchill wanted their sentences to be revised, and for them to be treated as political exiles rather than convicts, who could be allowed home when the unrest ceased. ${ }^{126}$ Without such conditions, he did not feel that the policy could be justified in the House of Commons.

On Elgin's prompting, McCallum raised Tilonko's case with his Minister of Justice, impressing on him the fact that he 'did not actually fight us'. However, Natal's ministers refused to budge: not only was he 'recognized as one of the principal leaders in rebel movement in Natal' but he had 'maintained to the last his attitude of defiance after arrest, and enlisted on his side, for the purposes of appeal to the Privy Council, that small but active section of English-speaking persons who regard rebellious and dangerous characters as useful instruments for the furtherance of political animosities' ${ }^{\text {I27 }}$ Officials in London also remained uncomfortable about using the Colonial Prisoners Removal Act: for, although its wording specified that it was to be used where 'the removal of the prisoner is expedient for his safe custody or for more efficiently carrying his sentence into effect', ${ }^{\mathrm{I} 28}$ Natal's intention was to use it (as Cox pointed out) 'to alarm and impress other natives who may be contemplating rebellion'. ${ }^{229}$ Natal's insistence on a tough policy caused major discomfort in Whitehall. 'Unless I can prove that our action has diminished \& substantially diminished the total sum of human pain', Churchill minuted, 'there will be grave inconvenience.' ${ }^{\text {I30 }}$

${ }^{124}$ Governor to Secretary of State, I7 February I907, CO I79/240/4452, f. I3 8.

${ }^{125}$ Sir C. Boyle (Governor of Mauritius) to Elgin, I7 January I907, CO I67/778/60I 7. The general correspondence relating to the removal is in PP 1907 (Cd. 3563) LVII. $38 \mathrm{I}$.

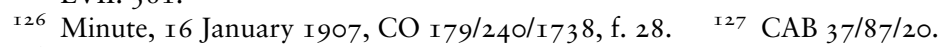

${ }^{128} 47 \& 48$ Vic. c. 3 I, s. 2(d). ${ }_{\text {I29 }}$ CO I $67 / 778 / 2786$.

${ }^{130}$ Minute, 2 I January I907, CO I79/243/2605, f. I 83 . 
In the event, the plan to deport them to Mauritius collapsed due to the outbreak of beri-beri on the island. Natal's ministers, ever anxious that the continued presence of the rebels in Natal might encourage revolt, urged that the men be sent to Mauritius, and kept in temporary buildings, fenced-off from other prisoners, as had been done with Boer prisoners of war, where they might be quarantined from the outbreak. But they were undone by their own insistence that the men be treated simply as removed prisoners: Cox determined 'to ram this point into the wooly ministerial heads in Natal' that '[i]f they deport them as convicts as convicts they must be treated.' ${ }^{\text {I3 I }}$ As ever, the colonial government seemed to have a rather more cavalier approach to legality than officials in Whitehall, whose own views of the matter were shaped by the political pressures they needed to respond to.

With deportation to Mauritius out of the question, the Natal government turned once more to St Helena, whose Governor agreed to take the twenty-five rebel leaders. ${ }^{\mathrm{I} 2}$ By then, some officials in London were sympathetic to Natal's view. Given recent reports on Dinuzulu's activities, Lambert noted, 'The whole situation is dangerous and the moral is I think that we should do what we can to help Natal by taking the 25 ringleaders at St Helena as soon as possible.' ${ }^{\text {I33 }}$ The legal procedure to remove them began at the end of April, with the Colonial Office ensuring that all the legal formalities were punctiliously followed. Winston Churchill protested, minuting that 'This is highly irregular; if not actually illegal. I cannot concur in any degree in this indefensible transaction: nor will I defend it.' ${ }^{\text {'34 }} \mathrm{On}$ I June, the rebel leaders left Natal by the steamship Inyati. ${ }^{\mathrm{I} 5}$ Although Elgin was informed that Natal's Prime Minister, F. R. Moor, had given instructions (when departing on leave) that Tilonko should not be deported, he was one of the prisoners on the ship. ${ }^{136}$ The Acting Prime Minister informed McCallum that the rest of the Cabinet felt

${ }^{\text {I3I }}$ Minutes, 5-6 March I907, CO I79/240/824I, ff. 25I, 258. London had developed its own plans to ameliorate the conditions for the prisoners on Mauritius, which would require local legislation there: $\mathrm{CO}$ I $67 / 778 / 2786$.

${ }^{132}$ PP 1907 (Cd. 3563 ), No. I9, p. 8.

${ }^{133}$ Minute, 2 I March I907, CO I 79/240/9666, f. 20I. Lambert referred to the despatch printed in PP I908 (Cd. 3888 ) LXXII. 47, No. I4, p. 20.

${ }^{134}$ See CO 879/106/6, No. 250, p. 90; minute of 25 April 1907, CO I79/240/I4392, f. 457 .

${ }^{135}$ PP 1907 (Cd. 3563), No. 26, p. I4. ${ }^{136}$ CO 879/106/6, No. 293, p. 103. 
the suggestion was 'quite impracticable' and took no action. Colonial Officials were sympathetic to these views, but Churchill saw it as 'Another piece of Natal blackguardism \& bad faith'. ${ }^{137}$ Of the twentyfive deported chiefs, seventeen had been tried by courts martial which had been set up after the Natal Assembly had passed the Indemnity Bill.

\section{Tilonko's Final Challenges}

Tilonko's deportation did not end his supporters' efforts to secure his liberty before the Privy Council. After the failure of the attempt to appeal the decision of Natal's Supreme Court to refuse him habeas corpus, Jellicoe and Colenso returned to the King's Bench in October, seeking judicial review of the decision to remove him under the Colonial Prisoners Removal Act. On this occasion, Jellicoe raised the same argument which had worried officials in Whitehall - that the legislation allowed removal only for 'safer custody' or for carrying out the sentence 'more efficiently'. He argued that material in the African Blue Book showed that the removal was designed to put an end to the rumour that the Home Government was about to order the release of all prisoners. The motion was refused by Lord Alverstone CJ, who disagreed with this interpretation of the facts. Deportation was necessary, he held, to prevent disorder; and the Secretary of State had acted within his powers. ${ }^{138}$ Jellicoe's first application was made before he had obtained a copy of the deportation order from the Colonial Office; but, having received a copy, he tried again. Besides challenging the order on technical grounds, he rehearsed the broader arguments he had made before the Privy Council: that Tilonko had not been legally imprisoned and that the Indemnity Act was invalid. Even if the Act itself could be said to be valid, he argued, it could not validate a sentence passed on 17 August, since the parliament which passed it had been dissolved in ${ }_{5} 5$ August 1906. On this occasion, Justices Darling and A. T. Lawrence rejected the application. The technical objection - that the date of conviction had been wrongly entered - was dismissed as not affecting the validity of the order. On the substantive

\footnotetext{
${ }^{137}$ Governor to Secretary of State, 2 June 1907, and minute by Churchill, 4 June I907, CO I79/24I/I9778, ff. 248-249.

${ }^{13} 8$ Exp. Tilonko, The Times, I4 October 1907, p. 4.
} 
questions, the King's Bench Division judges held that the Indemnity Act had been validly passed and that it had been prospective as well as retrospective. ${ }^{\mathrm{I} 39}$ In the court's view, Elgin had ample evidence for making the order; indeed, in view of the advice of the Colonial Government, he could not have done otherwise. The court did not look closely at the purpose of the I 884 Act which had so troubled officials, let alone the broader constitutional questions raised by Jellicoe.

Tilonko's legal team continued to press their point. In January I908, an unsuccessful attempt was made to sue Justice Beaumont and Governor McCallum in the Natal Supreme Court, the former for violating the Star Chamber Act of I64I (when refusing habeas corpus), and the latter for Tilonko's wrongful imprisonment. ${ }^{\mathrm{I}}{ }^{\circ}$ In May, Jellicoe applied once more to the Privy Council to appeal from this judgment. The Privy Council judges considered this as simply another attempt to raise the question about the correctness of the Natal court's decision to refuse habeas corpus, on which they had already pronounced in July I907. When Jellicoe sought to argue that the court had not previously considered his arguments about the validity of the Indemnity Act, Lord Macnaghten dismissed the attempted argument as hopeless. He explained that the court could only consider whether the Act had passed, and not pronounce on its wisdom. ${ }^{\text {III }}$ Once more, the Privy Council declined to consider Jellicoe's substantive arguments, taking a narrow view of legality: a statute was a statute, whatever it did to a subject's rights.

The argument that Natal's Indemnity Act was invalid because of the nature of its passing might have merited more consideration. It was trite law that the Royal Assent had to be given in England while parliament was sitting. Nor was it self-evident that Natal's I 893 Constitution Act - which provided for the crown to legislate with the advice and consent of the Legislative Council and Assembly - set a different rule. For although the Governor was then instructed not to assent to certain measures unless he had previously been given instructions on them, or unless a suspending clause was included in

\footnotetext{
${ }^{139}$ Notes from solicitors Sutton, Ommanney \& Rendall, 26 November 1907, CO I79/ $243 / 37445$, f. 522.

${ }^{1} 4 \circ$ The Times, 27 January I908, p. 5 .

${ }^{\mathrm{I}} \mathrm{I}$ Tilonko v. Attorney General of Natal, in The Times, 28 May I908, p. 3.
} 
the measure, the Act did not specifically provide for him to assent after a parliament had been dissolved. Given that different colonies with responsible government had varying provisions for the crown to reserve bills for approval (or disallowance) in London, the question of the possible invalidity of Natal's statute might have offered the chance for complex constitutional debate. Significantly, however, the Privy Council opted to have no debate on the matter at all.

Jellicoe and Colenso continued to try to keep Tilonko's case in the public eye. In June I908, a petition was presented to parliament, asking for an inquiry into his imprisonment. ${ }^{\mathrm{I} 2}$ At the end of the year, Jellicoe sent a petition from Tilonko and Colenso to the Lord Chancellor, asking for the case to be investigated by the 'magnum concilium' or High Court of Parliament. Having failed in all other avenues, this was an attempt to invoke a medieval form of petitioning. This one last attempt to find a legal venue to consider Tilonko's case again raised legal conundrums for officials to ponder. The application left the permanent secretary, Sir Muir McKenzie, somewhat nonplussed as to how to proceed. ${ }^{43}$ Having asked both the clerk to the Crown in Chancery and the clerk to the Commons for their observations, H. W. Just referred the matter to the Law Officers, who confirmed that the petitions were 'wholly irregular in form and no action can be taken upon them'. ${ }^{\text {I4 }}$

Tilonko returned to South Africa in I910, along with the other prisoners who had been sent to St Helena. Their return followed the release of Dinuzulu, who had been sentenced to four years' imprisonment after his 1908 conviction on some of the lesser charges of which he had been accused in the special court set up to try him. After he had been released by Louis Botha, the first Prime Minister of the new Union of South Africa, an order was given also to allow the St Helena exiles to return to Natal, though not to their own homes.

\section{Conclusion}

In many ways, the authorities both in London and in Pietermaritzburg found themselves in uncharted waters in 1906. Martial law remained

\footnotetext{
${ }^{142}$ The Times, I6 June I906, p. 5. $\quad{ }^{143}$ Manchester Guardian, I January I909, p. 3.

${ }^{144}$ Opinion of 8 February I909, CO 885/I6, No. I09.
} 
a grey area, with few clear rules to guide officials. Towards the end of May 1906, McCallum wrote to Elgin that nothing definite had ever been laid down to guide the Governor dealing with martial law in a colony with responsible government. While the I 867 instructions to crown colonies guidelines were useful as a general guide, 'I have had to depend on the exercise of common sense in the absence of precedents. ${ }^{\text {I45 }}$ At the height of the crisis over the proposed pardons for the Richmond convicts, he had told Elgin that the previous seven weeks had been 'a time to me of very grave anxiety' since there were no precedents to guide a Governor 'in the case of a responsible Government with a huge black population practically in rebellion'. ${ }^{46}$ By the time he came to leave Natal, in April I907, McCallum took the opportunity to suggest to the Colonial Office that the government should draw up general instructions to guide Governors in future cases. Officials were keen to let it lie. Vernon noted that 'there is a danger of the issue of instructions obscuring the most important of all facts about martial law, viz. that it is in its very nature illegal.' Cox added that there would be political dangers in laying down instructions for martial law: 'It wd be said that we were endeavouring to create a despotic system to be brought into force at the will of every Governor.' Indeed, in his view, the very difficulty of its administration was a deterrent to its use. ${ }^{\mathrm{I}}{ }^{7}$ This was, perhaps, wishful thinking. On 7 December 1907, on the unanimous advice of his ministers, McCallum once again proclaimed martial law, even though in his view it was (in the absence of any armed resistance to the ordinary processes of law) 'premature'. ${ }^{\mathrm{I} 8}$ On this occasion, martial law served the government's purpose of preventing Jellicoe - who had gone to Natal to defend Dinuzulu - from getting access to witnesses or visiting Zululand. ${ }^{\text {I } 99}$

Whitehall and Pietermaritzburg clearly had different conceptions of the rule of law. At the Colonial Office, officials were constantly

\footnotetext{
${ }^{145}$ Governor to Secretary of State, 25 May I906, CO I79/235/21 572, f. IO2.

${ }^{146}$ Governor to Secretary of State, CO 879/92/26, No. 9, p. I 2.

${ }^{147}$ Governor to Secretary of State and officials' notes, I2 April 1907, CO I79/240/ I6II6, f. 399 .

${ }^{148}$ Governor to Secretary of State, 3 December 1907, PP I908 (Cd. 3888), No. 74, p. 174 .

${ }^{149}$ Marks, Reluctant Rebellion, p. 263.
} 
worried about the legality of the steps which were being taken. Despite some disagreements among officials, they generally took a Diceyan view of the ambit of martial law, according to which acts done under martial law would ultimately have to be justifiable either in the courts (which retained a supervisory power, at least to determine whether the necessity for martial law existed) or before the political court of parliament. In part, their fidelity to this culture of the rule of law was prompted by the ever-present watchfulness of members of parliament and the press, who were able to monitor every step as a result both of modern communications and of the governmental openness dictated by the Blue Books. From the perspective of Pietermaritzburg, things looked very different: both ministers and the settler population were driven by the need to suppress African unrest and reimpose imperial rule. Natal's ministers and ministry felt the need to make examples of men like Tilonko. In response, officials at the Colonial Office, mindful of the need to respect the rights of responsible governments, tended to give way, and try to make their excuses at Westminster.

This left the defence of the rule of law to the courts, and in particular, the highest imperial court, the Judicial Committee of the Privy Council. However, this court did not see fit to intervene in the cases of these obscure Africans to uphold the vision of the rule of law found in chapter 29 of Magna Carta. Although in Tilonko's first case, Lord Halsbury accepted the Diceyan principle that courts could examine the necessity for martial law, he never applied the principle: it was simply overlooked in Mgomini's case, where the Privy Council simply deferred to the judgment of executive, while in Tilonko's case, it was held to have been rendered irrelevant by the Indemnity Act which had passed.

Although English jurists continued to pride themselves on having a constitution which subjected all to the rule of law, the effect of litigation and legislation of 1906 was to recognise that English law and imperial law - did in practice provide for a state of siege. Once the executive had proclaimed martial law, the courts would not (according to Halsbury's approach in Mgomini) look behind it; once an Indemnity Act had been passed, the court would do nothing (according to Tilonko) but obey. In between the two, it was now legally open for governments to follow Natal's path of keeping a proclamation of 
martial law in force until its work had been done, and ratifying all acts under it by pre-ordered indemnities. Fidelity to the rule of law would depend on political pressure rather than the protection of the Judicial Committee of the Privy Council; but, in the world of imperial politics, the rights of Africans did not have a high political priority. 